\title{
Off Observation
}

National Cancer Institute

\section{Source}

National Cancer Institute. Off Observation. NCI Thesaurus. Code C154662.

No longer subject to surveillance. 